\title{
Faktor-faktor yang Berhubungan dengan Konsumsi Vitamin A oleh Ibu Nifas di Wilayah Kerja Puskesmas Bungi Kota Baubau
}

\author{
Poniasih Lelawatty
}

Program Studi DIII Farmasi Politeknik Bau-bau, Jl. Lakarambau Kota Baubau 93721

E-mail: lewatyp@gmail.com

\begin{abstract}
Abstrak
Beberapa faktor penyebab berhubungan dengan mengonsumsi vitamin A oleh ibu nifas seperti faktor pengetahuan, kurangnya penyuluhan atau sosialisasi, akses informasi, konseling. Faktor-faktor ini berkaitan erat dengan ketercapaiannya target mengonsumsi vitamin A khususnya ibu nifas di wilayah kerja Puskesmas Bungi Liabuku. Penelitian ini faktor yang diteliti yang berhubungan dengan mengonsumsi vitamin A oleh ibu nifas hanya faktor pengetahuan dan faktor konseling. Penelitian ini bertujuan untuk mengetahui faktor pengetahuan dan faktor konseling berhubungan dengan mengonsumsi vitamin A oleh ibu nifas. Hipotesis pada penelitian ini adalah ada hubungan faktor pengetahuan dan hubungan faktor konseling dengan mengonsumsi vitamin A oleh ibu nifas. Metode penelitian yang digunakan adalah metode deskriptif survey dengan pendekatan cross sectional. Teknik pengambilan sampel adalah Total sampling atau jumlah populasi sama dengan jumlah sampel yaitu 29 ibu nifas. Hasil penelitian ini menunjukkan bahwa dari $29 \mathrm{ibu}$ nifas yang memiliki pengetahuan baik berhubungan dengan mengonsumsi vitamin A sebanyak $5(17,2 \%)$ dan ibu nifas yang berpengetahuan kurang berhubungan dengan mengonsumsi vitamin A sebanyak $9(31,0 \%)$ ibu nifas . Selanjutnya dari 29 ibu nifas, yang memperoleh konseling dengan baik berhubungan dengan mengonsumsi vitamin A sebanyak1 (3,4\%) ibu nifas dan konseling kurang berhubungan dengan mengonsumsi vitamin A sebanyak 14 (48,3\%) ibu nifas. Simpulan pada penelitian ini adalah ada hubungan dengan tingkat keeratan hubungan rendah faktor pengetahuan dan faktor konseling dengan mengonsumsi vitamin A oleh ibu nifas.
\end{abstract}

Kata kunci: pengetahuan, konseling, vitamin, konsumsi, nifas

\section{Pendahuluan}

Masa nifas adalah proses pemulihan alat-alat reproduksi seperti sebelum hamil (involusi), berlangsung secara bertahap membutuhkan waktu yang berbeda-beda setiap orangnya, biasanya berlangsung sekitar 40 hari. Untuk mempercepat proses involusi uteri di butuhkan nutrisi yang baik salah satunya dengan mengonsumsi vitamin A [1].

Pada masa nifas di perlukan suatu asuhan yang bertujuan untuk menjaga kesehatan ibu dan bayinya, baik fisik maupun psikologis serta memberikan pendidikan kesehatan tentang perawatan kesehatan diri, nutrisi, KB, menyusui, pemberian imunisasi kepada bayinya dan perawatan bayi sehat. Pada asuhan masa nifas yang berhubungan dengan nutrisi, ibu nifas mempunyai kebutuhan dasar yaitu mengonsumsi vitamin A [2, 7].

Salah satu akibat yang yang ditimbulkan karena kekurangan vitamin A yaitu penyakit Xeropthalmia. Indonesia dinyatakan bebas dari masalah Xeropthalmia (kelainan pada retina mata karena kekurangan vitamin A) tahun 2007, namun 50\% ibu nifas mempunyai serum retinol kurang dari $20 \mathrm{ug} / \mathrm{dl}$ yang akan berdampak pada resiko kebutaan dan kematian karena infeksi $[1,6]$.

Survey pemetaan yang pernah dilakukan di provinsi Kalimantan Barat tahun 2006, dilaporkan bahwa prevelensi
Xeropthalmia sebesar 0,12\% lebih rendah dari batas WHO (World Health Organization) yaitu sebesar 0,15\%. Namun bila dilihat dari kecenderungan pencapaian cakupan konsumsi kapsul vitamin A yang mengalami penurunan sejak tahun 2005, dikhawatirkan akan muncul kembali kasus tersebut [1].

Saat ini defisiensi vitamin A masih di alami oleh negara-negara berkembang termaksud Indonesia. Salah satu cara untuk mengatasi masalah tersebut yaitu melalui program suplementasi vitamin A pada ibu nifas. Dari beberapa faktor yang berhubungan dengan cakupan mengonsumsi vitamin A oleh ibu nifas antara lain faktor pengetahuan dan konseling [3].

Menurut WHO di tahun 2010 setidaknya di perkirakan masih terdapat 1 dari 4 ibu nifas yang mengonsumsi Vitamin A. Data dari Depkes RI tahun 2012 jumlah ibu nifas yang mengonsumsi Vitamin A di Indonesia masih rendah yaitu 51,65\% dari cakupan target $90 \%$ [3].

\section{Metode}

\subsection{Uтит}

Jenis penelitian yang di gunakan adalah jenis penelitian deskriptif asosiatif dengan pendekatan data cross 
sectional study. Lokasi penelitian ini bertempat di Wilayah Kerja Puskesmas Bungi Kota Baubau sejak bulan OktoberNovember. Populasi dalam penelitian ini adalah semua ibu Nifas di Wilayah Kerja Puskesmas Bungi Kota Baubau dengan jumlah populasi 29 orang ibu nifas, data dari bulan Januari-Juli pada tahun 2017. Sampel dalam penelitian ini adalah populasi yang terpilih sebagai sampel. Metode yang digunakan adalah total sampling jadi sampel dalam penelitian ini yaitu sebanyak 29 orang ibu nifas. Pengumpulan data menggunakan instrumen dalam bentuk lembar kuisioner. Menggunakan analisis data univariat yang disajikan dalam bentuk tabel distribusi frekuensi dan bivariat yang disajikan dalam bentuk analisis tabulasi silang untuk beberapa variabel

\section{Hasil dan Pembahasan}

Sebanyak 29 ibu nifas sebagai sampel penelitian, 15 ibu nifas $(51,7 \%)$ diantaranya memiliki pengetahuan yang baik, dan 14 orang $(48,3 \%)$ ibu nifas memiliki pengetahuan kurang. Jumlah ibu nifas yang memperoleh konseling dengan baik sebanyak 16 ibu nifas $(55,2 \%)$ dan $13 \mathrm{ibu}$ lainnya $(44,8 \%)$ kurang memperoleh konseling yang baik. Selanjutnya sebanyak 6 ibu nifas $(27,7 \%)$ memiliki pengetahuan baik berhubungan dengan mengonsumsi vitamin A serta mengatakan baik, 9 ibu nifas (31,0\%) menyatakan kurang, dan jumlah seluruh ibu nifas yang memiliki pengetahuan baik sebanyak 15 ibu nifas $(51,7 \%)$. Selain itu, terdapat 14 ibu nifas $(48,3 \%)$ yang memiliki pengetahuan kurang.

Berdasarkan hasil analisis uji chi square $\left(X^{2}\right)$ di peroleh nilai korelasi sebesar 7,061 dengan mempunyai tingkat kepercayaan yang ditetapkan sebesar 0,05 artinya $\mathrm{H}_{\mathrm{o}}$ ditolak dan $\mathrm{H}_{\mathrm{a}}$ diterima atau tingkat kepercayaan $>X^{2}$ tabel $=3,481$ dengan tingkat kepercayaan yang ditetapkan sebesar 0,05 atau tingkat kepercayaan yang ditetapkan lebih besar dari nilai $\rho_{\text {value }}$ yaitu $\alpha=0.05>\rho=0,008$ dengan koefisien korelasi $r=0,442$. Dapat disimpulkan bahwa ada hubungan yang cukup erat antara faktor pengetahuan dengan konsumsi vitamin A oleh ibu nifas.

Hasil penelitian mempelihatkan dari 29 ibu nifas, yang memperoleh konseling dengan baik berhubungan dengan mengonsumsi vitamin A serta mengatakan baik terdapat 1 ibu nifas $(3,4 \%)$ dan mengatakan kurang terdapat 15 ibu nifas $(51,7 \%)$ dan jumlah seluruh ibu nifas yang berhubungan dengan konseling baik sebanyak 16 ibu nifas $(55,2 \%)$. Selanjutnya dari 29 ibu nifas yang yang memperoleh konseling kurang berhubungan dengan mengonsumsi vitamin A mengatakan baik terdapat $5 \mathrm{ibu}$ nifas $(20,7 \%)$ serta mengatakan kurang 8 ibu nifas $(27,6 \%)$ dan seluruh jumlah ibu nifas yang berhubungan dengan konseling kurang sebanyak 13 ibu nifas (44,8\%).

Berdasarkan hasil analisis uji chi square $\left(X^{2}\right)$ diperoleh nilai korelasi sebesar 4,535 dengan mempunyai tingkat kepercayaan yang ditetapkan sebesar 0,05 artinya $\mathrm{H}_{\mathrm{o}}$ ditolak dan $\mathrm{H}_{\mathrm{a}}$ diterima atau tingkat kepercayaan $>X^{2}$ tabel $=3,481$ atau tingkat kepercayaan yang ditetapkan lebih besar dari nilai $\rho_{\text {value }}$ yaitu $\alpha=0.05>\rho=0,033$, serta telah diketahui nilai koefisien korelasi yaitu $r=0,368$. Hal ini menunjukkan adanya hubungan yang kurang erat antara faktor konseling dengan mengonsumsi vitamin A oleh ibu nifas.

Sebanyak 5 ibu nifas $(17,2 \%)$ mengatakan faktor pengetahuan dan konseling berhubungan dengan mengonsumsi vitamin A, 9 ibu nifas $(31,0 \%)$ menyatakan kurang berhubungan, serta 14 lainnya $(48,3 \%)$ menyatakan faktor pengetahuan dan konseling tidak berhubungan. Selanjutnya dari jumlah seluruh ibu nifas yang mengatakan faktor pengetahuan dan konseling berhubungan dengan mengonsumsi vitamin A terdapat 15 ibu nifas $(51,7 \%)$ yang menyatakan baik.

Berdasarkan hasil analisis uji diperoleh nilai $X^{2}$ hitung $=3,724>X^{2}$ tabel $=3,481$ dengan tingkat kepercayaan yang ditetapkan sebesar 0,05 artinya $\mathrm{H}_{\mathrm{o}}$ ditolak dan $\mathrm{H}_{\mathrm{a}}$ diterima atau tingkat kepercayaan $>X^{2}$ tabel $=3,481$ atau tingkat kepercayaan yang ditetapkan lebih besar dari nilai $\rho_{\text {value }}$ yaitu $\alpha=0.05>\rho=0,054$, dengan koefisien korelasi yaitu $r=0,337$. Artinya bahwa ada hubungan dengan tingkat keeratan hubungan rendah pada faktor-faktor yang berhubungan dengan mengonsumsi vitamin $\mathrm{A}$ oleh ibu nifas.

Pengetahuan yang baik akan sangat berpengaruh pada perubahan pola pikir yang baik. Ibu nifas yang memilki pengetahuan yang baik tentang vitamin A akan mengetahui pentingnya mengonsumsi vitamin A. Sebaliknya, ibu nifas yang masih kurang pengetahuannya tentang vitamin A tidak akan mengetahui pentingnya mengonsumsi vitamin A. Penelitian ini mengacu pada dukungan teori yang menyatakan bahwa pengetahuan ialah hasil tahu yang terjadi dan terwujud setelah seseorang melakukan pengindraan terhadap suatu objek tertentu. Pengetahuan atau kognitif merupakan domain yang sangat penting untuk terbentuknya tindakan seseorang (overt behavior). Dengan demikian, tanpa pengetahuan banyak orang akan salah mengambil keputusan dan pilihan. Untuk mendapatkan sebuah pengetahuan seseorang harus melewati proses belajar, mencari, mengamati dan menganalisis [4].

Hasil analisis uji chi square $\left(X^{2}\right)$ diperoleh nilai korelasi sebesar 7,061 dengan tingkat kepercayaan yang ditetapkan sebesar 0,05 artinya $\mathrm{H}_{\mathrm{o}}$ ditolak dan $\mathrm{H}_{\mathrm{a}}$ diterima atau tingkat kepercayaan $>X^{2}$ tabel $=3,481$ atau tingkat kepercayaan yang ditetapkan lebih besar dari nilai $\rho_{\text {value }}$ yaitu $\alpha=0.05>\rho=0,008$, serta telah diketahui nilai koefisien korelasi yaitu $r=0,442$. Hal ini menunjukkan adanya hubungan dengan tingkat keeratan hubungan sedang antara faktor pengetahuan dengan mengonsumsi vitamin A oleh ibu nifas di wilayah kerja Puskesmas Bungi Kota Baubau tahun 2017.

Konseling yang baik akan sangat berpengaruh dalam perubahan pola pikir dan perilaku suatu individu. Konseling yang baik akan sangat membantu ibu nifas memahami maksud dan tujuan dari pentingnya mengonsumsi vitamin A khususnya bagi ibu nifas. Konseling berarti, interaksi yang terjadi antara dua orang individu, masing-masing disebut konselor dan klien. Terjadi dalam suasana yang profesional, dilakukan dan dijadikan sebagai alat untuk memudahkan dan memberikan suatu pemahaman-pemahaman serta perubahan-perubahan dalam tingkah laku dan atau pola pikir klien $[5,6]$. Berdasarkan hasil analisis uji Chi Squer Kuadrat $\left(X^{2}\right)$ di 
peroleh nilai korelasi sebesar 4,535 dengan tingkat kepercayaan yang ditetapkan sebesar 0,05 artinya $\mathrm{H}_{\mathrm{o}}$ ditolak dan $\mathrm{H}_{\mathrm{a}}$ diterima atau tingkat kepercayaan $>X^{2}$ tabel $=3,481$ atau tingkat kepercayaan yang ditetapkan lebih besar dari nilai $\rho_{\text {value }}$ yaitu $\alpha=0.05>\rho=0,033$, serta telah diketahui nilai koefisien korelasi yaitu $r=0,368$. Hal ini menunjukkan ada hubungan yang rendah antara faktor konseling dengan mengonsumsi vitamin A oleh ibu nifas di wilayah Kerja Puskesmas Bungi Kota Baubau

\section{Kesimpulan}

Terdapat hubungan variabel penelitian (faktor pengetahuan dan faktor konseling) dengan mengonsumsi vitamin A oleh ibu nifas di wilayah kerja Puskesmas Bungi Kota Baubau tahun 2017, sehingga diharapkan agar ibu nifas lebih sering mengakses informasi mengenai vitamin A dan lebih aktif dalam menghadiri kegiatan-kegiatan penyuluhan yang diadakan oleh tenaga kesehatan.

\section{Daftar Pustaka}

1. Durianti E, Sari USC, Dianna, Pengetahuan vitamin A ibu nifas di wilayah kerja Puskesmas Tiong Keranjik Kabupaten Melawi, Jurnal Vokasi Kesehatan, 2015, 1(6).

2. Manuaba IGB, Ilmu Kebidanan Penyakit Kandungan Dan $K B$, Jakarta: Penerbit Buku Kedoteran EGC, 2010.

3. Safitri MR, Briawan B, Hubungan antara suplementasi Vitamin A pada ibu nifas dan mordibitas bayi umur 0-6 bulan di Kecamatan Ciampea, Kabupaten Bogor, Jurnal Gizi dan Pangan, 2013, 8(2).

4. Notoatmodjo S, Kesehatan Masyarakat, Jakarta: Rineka cipta, 2011.

5. Purwoastuti E, Komunikasi dan Konseling Kebidanan, Yogyakarta: Pustaka Baru Press, 2015.

6. Herman S, Masalah Kurang Vitamin A (KVA) dan Prospek Penanggulanganya, Media Litbang Kesehatan, 2007, XVII(4);40-44.

7. Herawati BM, Perilaku tenaga kesehatan dalam memberikan pendidikan kesehatan dengan perilaku ibu dalam pemberian kapsul Vitamin A pada anak berusia 6-59 Bulan, Dunia Keperawatan, 2015, 3(2); 88-89.

(c) (i) 2019 by the authors; This article is an open access article distributed under the terms and conditions of the Creative Commons Attribution License (http://creativecommons.org/ licenses/by/4.0/) 